\title{
Middle Income Convergence Trap and the Role of Competition Policy in SEE Countries
}

\author{
Boris Begović
}

\section{Introduction}

Economic growth is the paramount objective of the SEE countries. ${ }^{1}$ That is quite understandable: the Region is still the poor side of Europe, as it has been for decades. Rosenstein-Rodan (1943), in his seminal contribution to the theory of development, declared the main reason of underdevelopment in SEE as an "international depressed area". ${ }^{2}$ Over the past century, there was no real convergence of the SEE countries towards Western European productivity and living standards. Maddison (2007) demonstrated that the per capita income differences between the two regions have even increased during that period. ${ }^{3}$

Accordingly, in this paper the role of competition policy is evaluated only from the perspective of speeding up the long-term economic growth of the SEE countries. It is presumed that there is no other aim of competition policy but to increase the economic growth rate to the optimal one. ${ }^{4}$ Although a dynamic notion, growth rate optimisation can be compared to social welfare criteria, which is a static notion, commonly used as the standard in competition law enforcement.

\footnotetext{
${ }^{1}$ For the purpose of this paper, SEE countries are: Albania, Bosnia and Herzegovina, Bulgaria, Croatia, Greece, FYR Macedonia, Moldova, Montenegro, Romania and Serbia.

${ }^{2}$ Even though the author considers SEE together with East Europe, as a single region: "everything between Germany, Italy and Russia".

${ }^{3}$ According to Maddison (2007), Western Europe per capita income was 2.04 time higher than per capita income of Eastern Europe in 1913. This ratio increased to 3.07 in 2003. Although there is no separate calculation for the SEE, it is presumed that the ratio is even higher. Begović (2013) provided some political economy explanation for the lack of the convergence.

${ }^{4}$ The economic growth rate optimisation is based on the "Golden Rule" (Phelps 1966), specified as the saving rate that maximises steady state consumption.

B. Begović

Faculty of Law, University of Belgrade, Belgrade, Serbia

e-mail: begovic@ius.bg.ac.rs
} 
The aim of the paper is to explore whether and what kind of competition policy is desirable for SEE countries using growth rate optimisation as the criterion. Taking that into account, the possibility of SEE countries being caught in the middle income convergence trap must be explored. The structure of the paper is devised accordingly. First, the mechanics of the middle income convergence trap is explored. Next considered is the hypothesis about different competition policies being suitable for different levels of economic development. The answer to the question about whether SEE countries are in the middle income convergence trap follows. A key segment of the paper follows, with a suggestion regarding the desirable elements of competition policy for the SEE counties. Conclusion ends the paper.

\section{Engines of Economic Growth: The Mechanics of Middle Income Convergence Trap}

There are basically two engines of economic growth: the accumulation of production factors, i.e. their investment into production, and the increase of total factor productivity (TFP) due to improvements of efficiency and due to the technological progress, i.e. innovations.

Accumulation of the production factors is crucial for growth at lower levels of economic development (measured by lower levels of per capita income), i.e. for growth of the countries that are far from the technological frontier. Many production factors, especially labour, are not utilised at all, capital is scares due to the low income and low saving rate, and within such a framework, marginal productivity of investments is rather high. That is good for both economic growth and for investors, since high returns provide strong incentives for investments to materialise. The problem with this mechanism of growth is that it is not sustainable. As it has been demonstrated even by early models of exogenous growth (Solow 1956), accumulation of production factors can achieve only transitory economic growth. When the steady state is achieved, due to the inevitable equalisation of the investment rate and the deprecation rate, i.e. when capital per labour is constant, economic growth depends only on the increase of the TFP due to the technological progress that is exogenous to the model. ${ }^{5}$

A crucial prerequisite for this type of economic growth, i.e. investment based growth, is high expected investment returns, as only such returns provide incentive for investment. If returns are low or if the probability of returns and/or investments expropriation is high, then expected returns are low, providing weak or no incentive for investors to invest physical capital. Since capital is a mobile production factor, it is welcomed in other industries and/or countries with higher expected returns. On the

\footnotetext{
${ }^{5}$ This insight is based on the implicit assumption that efficiency is maximised (Solow 1956), i.e. that there is no way to improve the efficiency and increase TFP on that basis. Accordingly, all the transitional economic growth in this model is based on production factor accumulation.
} 
one hand, product market competition is a strong mechanism for eliminating market power and the ability of incumbent firms to appropriate economic rent, hence decreasing expected returns in this way. On the other hand, rule of law provides protection of private property rights, decreasing the probability of expropriation, either by private or government predators, consequently increasing expected returns.

As previously pointed out, the increase in the TFP has two main sources. One is inefficiency that can be removed for a given technology, such as production inefficiency (with the endogenous average cost not being minimised) and allocative inefficiency (with prices above marginal costs). Both efficiencies can be eliminated or at least minimised by incentives created by competition, especially product market competition. A special type of inefficiency is inefficient industrial structure with substantial resources engaged in low-productivity activities. Competition, including production factors market competition and high mobility (due to low barriers) of the production factors, can provide for inter-industry reallocation of resources from low-productivity to high-productivity activities, consequently increasing of the TFP.

Like the above-described inter-industry reallocation of resources, competition provides for intra-industry reallocation of resources, due to the market selection among incumbents (Aghion et al. 1997; Aghion and Schankerman 2004), as it generates a larger market share for low-cost firms, at the expense of high-cost firm (with some of them exiting the industry). This leads to a decrease in average coststhe same outcome as improvement of production efficiency.

The main issue with increased efficiency as the source of TFP growth is that it is a one-off event; the reallocation of resources from low-productivity to highproductivity activities can be done only once-it is not sustainable. The only sustainable increase of the TFP is based on technological progress, i.e. innovations that improve the technology that is used in production. If a stead state is achieved, then growth rate is equal to the technology progress rate. Modern economic growth theory considers technological progress to be endogenous, based on research and development (R\&D) or, only locally, based on adoption of existing but superior technology - technology from the technological frontier. For a country/industry that is close to the technological frontier, the only means of technological progress, and in that way improved TFP, is own R\&D, and technological innovation as its outcome. For a country/industry that is far from the technological frontier, imitation, i.e. adoption of advance technology is an option, which not available to the former.

Investment based growth is the dominant engine of growth for poor countries, i.e. countries that are far from the technological frontier. This is quite expected, considering that scarcity of capital and low level of capital per worker provide for increasing returns in production and high returns for the investors. Furthermore, a substantial segment of the labour force is not engaged, hence accumulation of production factors is the inevitable first stage of economic growth of poor countries. Nonetheless, there is substantial room for improvement of efficiency in countries with a low level of per capita income. Accordingly, increased TFP due to the increased efficiency can substantially contribute as an additional engine of growth for these countries. 
The thesis that investment based growth, i.e. capital accumulation, is a prerequisite for economic growth of the countries that are far from the technological frontier has been challenged. Both Hall and Jones (1999) and Easterly and Levine (2001) pointed out that production factor accumulation is not crucial for economic growth of poor countries. They pointed out that difference in productivity, both in TFP and labour productivity, can successfully explain the differences in per capita income between the countries. In other words, it is not production factor accumulation that made now developed countries rich, but rather the increase of the TFP. Furthermore, a substantial part of the difference in productivity between the countries can be explained by different technologies that they use: modern, cutting-edge technology used by the countries that are on the technological frontier and traditional, obsolete technology used by countries that are far from the technological frontier. The only way for this gap to be closed is imitation, i.e. adoption of the modern technology in the poor countries. As substantial part of these technologies is embedded in physical capital, investments are needed for adoption of the modern technology that would improve the TFP. At the end of the day, it is investment based growth that is an indispensable engine of growth for the poor countries, although it is not the only one.

Innovation based growth is the dominant engine of growth for rich countries, which are close to the technological frontier. Investment based growth is not an option for them, since, due to diminishing returns of capital, they have already achieved steady-state in which growth depends only on innovations based on the technological progress. As these countries are on the technological frontier or very close to it, there is no way for them to imitate, i.e. to adopt technology from the countries that are technological superior-such countries do not exist. Furthermore, most of the inefficiencies have already been eliminated, hence there is very limited room for increasing TFP on that basis.

Acemoglu et al. (2006) pointed out that institutions suitable for investment based growth are not suitable for growth based on innovations. In principle, the success of investment based growth depends on the incentives to invest. That can, in principle, be subsidised by the government or government policy, based on the lack of competition policy and substantial legal barriers to entry, which provide for substantial rents appropriated by incumbents. As it was indicated (Acemoglu et al. 2006), it is rather difficult, or even unfeasible for less developed countries, those that need investments, to provide subsidies from their modest budgets, inevitably due to their limited income, and competing needs in provision of public goods. The only feasible institutional option is a lax or even absence of a competition policy and substantial legal barriers to entry. In that way excessive profits, created by market power and preserved by barriers to entry, turned into rent for investors, providing incentive for investment. ${ }^{6}$

\footnotetext{
${ }^{6}$ This approach does not consider rule of law, which provides universal protection of private property rights, as an institutional option for increasing expected returns on investment that would create incentives for investment. The justification for such an approach, if any, can be found in the insight that rule of law does not have a negative effect on innovation based economic growth.
} 
This institutional option has a substantial drawback because the lack of competition that it produces eliminates incentives for efficiency, and there are substantial inefficiencies in the countries that are on the low level of both economic and institutional development. Hence with such an institutional option, the prospect for a TFP increase contributing to growth is very slim. Furthermore, with no competition there is no incentive for adoption of modern technology, i.e. imitation of innovations, as no "escape competition" motive exists.

The situation is much more difficult in the case of developed countries, which are close to the technological frontier, because their growth depends only on innovations and only competition provides incentives for them. With no competition, with substantial market power enjoyed by undertakings, there is no incentive for any incumbent to invest in $\mathrm{R} \& \mathrm{D}$, an activity that creates technological innovations. This cannot be changed in situations with substantial legal barriers to entry, as there is no pressure from potential competition, and no new entries that can bring in innovations based on technological progress. With no resources allocated to $\mathrm{R} \& \mathrm{D}$, there is no technological progress, and no movement of the technological frontiers. Accordingly, institutions that are appropriate, at least up to a point, for low per capita income countries are entirely counterproductive for high per capita income countries, which are close to the technological frontier.

This is the foundation for the middle-income convergence trap. ${ }^{7}$ Investment based economic growth, established on the appropriate institutions, brings the country to the higher per capita income and closer to the technical frontier. Both real income and technological convergence starts. Nonetheless, by achieving that success, economic growth undermines its foundation-it is not sustainable any more, as the engine of investment based growth runs out of steam and can no longer produce results at the higher level of economic development, i.e. closer to the technological frontier. No further convergence, neither income nor technological, can be achieved. As theoretically demonstrated (Aghion et al. 2005), divergence follows, as growth continues in developed countries, those close to the technological frontier.

Innovation based growth should take over growth sustainability and further convergence. New, quite different institutions are needed, which produce incentives for innovations, i.e. for $R \& D$ which produces these innovations. The most important institutions are those that produce strong competition and enable free entry of newcomers. Intensive competition provides incumbent firms with strong incentives to invest in a pre-emptive decrease of production costs to obtain market power, i.e. "escaping competition" motive, and to prevent new, more efficient entries that

\footnotetext{
${ }^{7}$ Middle income trap in this paper is considered only as the middle-income convergence trap, i.e. the situation in which real income and technology convergence stalls. This trap is sometimes referred to in the literature as "non-convergence trap" (Aghion et al. 2005). Im and Rosenblatt (2013) provided an extensive review of various concept of middle-income traps, as well as other notions of traps in economic growth and development literature common parlance, some of them rather far away from the notion used in this paper. Without a clear specification of the main mechanism of the middleincome trap, empirical testing of the hypothesis produced mixed results (Han and Wei 2017).
} 
can undermine the rent that is appropriated by incumbents (Aghion et al. 2001; Aghion and Howitt 2006). Free entry, i.e. low barriers to entry, provides a classic Schumpeterian model of growth situation: a new, technologically superior, i.e. more efficient entry replaces the incumbent, which exits the industry. Furthermore, it was demonstrated (Aghion et al. 2009) that free entry also provides incentives for incumbents to innovate and increase their efficiency, although that incentive proved to be effective predominantly for the incumbent that are close to the technological frontiers, not so for those far from it. ${ }^{8}$ This leads to the equilibrium distribution of firm, including both incumbents and new entries (Acemoglu and Cao 2015).

The right timing of the shift from investment to the innovation based growth is essential for escaping middle income convergence trap. If the institutions suitable for innovation based growth are introduced too early, then investment based growth, the one that still enables convergence, is undermined. The absence of investments that is generated through the shift will not be compensated by increased innovations and growth will slow down - the convergence would come to an end. Contrary to that, if the institutions suitable for innovation based growth are introduced too late, then the engine of innovation based growth is constrained and investment based growth cannot compensate for that, so growth would slow down; convergence would again come to an end.

From the theoretical perspective, the model is symmetrical (Aghion et al. 2005): the threat of premature institutional reform is equal to the danger of delayed institutional reform. Since competition policy is an essential part of the institutions appropriate for the different engines of growth, the question is whether this is true for such a policy. Is the threat of premature introduction of competition policy greater than the danger of introducing it too late?

\section{Different Competition Policies for Different Per Capita Income Levels?}

Building on the insight related to the concept of dual engines of growth, it is possible to advocate different competition policies for countries at different per capita income levels, i.e. countries featuring different distances from the technological frontier.

Singh (2002) suggested that competition policy was counterproductive for poor countries, since their growth is based on investments and high returns on them, due to the market power, would be undermined by competition policy. Not only are the incentives for investment compromised in this way, but he also suggested that low retained earnings, due to the eliminated/limited market power, could not provide

\footnotetext{
${ }^{8}$ This finding, theoretically explained by Aghion and Howitt (2006), assumes that the new entries' technologies are on the technological frontier and was supported empirically by the case of the UK (Aghion et al. 2009). Some empirical support for this finding, in the case of the FDI in CEE, has been provided by Sabirianova et al. (2005), although not in China (Lu et al. 2017).
} 
sufficient funds to be reinvested. This argument, based on insights of imperfect or even missing capital markets and financial intermediation in poor countries (Laffonte 1998; Acemoglu et al. 2006), reinforces the recommendation against competition policy in countries far from the technological frontier. It is evident that a substantial legal barriers to entry should be introduced, as a necessary condition for the lack of competition policy effectiveness, since the economic profit of the incumbents, the main incentive for investment, would otherwise dissipate; free entry kills economic profit.

This argument against competition policy countries that are far from the technological frontier should be evaluated by taking into account a several insights. The first one is that the crucial incentive for investment is an expected value of their returns, not their magnitude, meaning that probability of the appropriation of the returns matters. It was empirically demonstrated (Akhtaruzzman et al. 2017) that protection of private property rights, i.e. protection of the investment as well as its returns, is much more important for expected returns on investments than the magnitude of the returns themselves, although the results are restricted to the FDI. ${ }^{9}$ Accordingly, introduction of rule of law, which decreases the probability of investment/capital expropriation, is much more important for investment decisions than the sheer magnitude of the returns, depending on the market power and ultimately on competition policy. It is rule of law that is a crucial incentive for investors, not the lax competition policy, or rather the lack of it. Hence, building institutions that provide rule of law and universal protection of private property rights is a priority in speeding up investment based economic growth.

The second insight is that increasing TFP, by increasing the efficiency of the incumbent firms and intra- and inter-industry reallocation of the resources from low-productivity to high-productivity activities with given technology, is an important source of growth for countries far from the technological frontier. With these inefficiencies being widespread there is substantial room for improvements of this kind and it takes time for the one-off improvement to materialise. Hence, the increase in the TFP, due to the improved efficiency, can contribute to economic growth for some time. A crucial incentive for improved efficiency is competition; with lax competition policy or rather without it, and the consequent substantial market power, this incentive would diminish, and there would be no restructuring or both intra- and inter-industry resource allocation from high-cost to low-cost activities. Economic growth would inevitably slow-down due to no contribution from the increase in the TFP. This effect countervails the effect of speeding up growth due to the higher expected returns and higher investment rates achieved by abandoning competition policy.

\footnotetext{
${ }^{9}$ Akhtaruzzman et al. (2017) considered expropriation risk as only one of the political risks that investors faced. The other two are redistributive taxation, and regulatory burden and government inefficiency. Accordingly, only expropriation by the government is considered and not expropriation by private predators. All explanatory variables proved to be highly statistically significant and robust in the econometric analysis encompassing 83 developing countries over 32 years in dynamic panel with fixed effects.
} 
Finally, the economic growth of countries far from the technological frontier depends on the speed of adoption of modern technology through international technology transfer. It is crucial to analyse the incentives for firms in these countries to adopt modern technology. An important insight for this analysis is that adoption of technology creates ex ante certain fixed costs, which are far below the size of the fixed cost of the R\&D that should produce innovation, and there is no uncertainty regarding the outcome of the process, unlike in the case of $R \& D$, but the fixed costs of technology transfer are still substantial and unavoidable since they provide the firm with adoption capacity. Accordingly, they can be compared to R\&D costs, by their character if not magnitude. Taking this into account, competition is a strong incentive for adoption of modern technology, similar to the "escape competition" mechanism of the Schumpeterian model of economic growth. A market power that would be created through adoption would provide rents that would compensate the fixed costs of that adoption. ${ }^{10}$ If there is no competition, there is no "escape competition" motive for adoption of modern technology, at least not for incumbent firms; they already have market power due to the absence of competition policy and the high barriers to entry.

Obviously, there are countervailing effects of the competition policy on the economic growth of the countries that are far from the technological frontier, so the question is which effect is dominant. The ultimate answer to this question is empirical. For the time being, there is no specific empirical research that directly addresses the issue, but there are some results that can provide clues about it. Empirical research has provided evidence that competition policy is good for economic growth without specifying whether it is good for the investment based or innovation based growth. Since the sample does not consist only of countries that are far from the technological frontier, the obtained results should be interpreted with caution. Dutz and Hayri (2000) used a cross-section the effective competition policy of 53 countries, demonstrating a statistically significant relationship between competition policy, as an explanatory variable, and economic growth, in the way that more competition policy accelerates economic growth. Petersen (2013) used panel data for 154 countries, from 1960 to 2005, and tested whether the introduction of competition law had an effect of economic growth. He found that there was a statistically significant and robust positive effect with a lag of 10 years. The explanation of the result is intuitive: the lag effect is both due to the lag on the part of the national competition agencies (NCAs), on account of making competition law enforcement more effective through learning-by-doing, and the part of undertakings, as it takes time for the deterrent effect of competition law enforcement to become effective.

\footnotetext{
${ }^{10}$ There are some substantial differences between the two "escape competition" mechanisms. In the case of innovation market power is specified in time, with protection of intellectual property rights, mainly patents. In the case of adoption of existing technology, there is no protection. Hence, expected values of rent in the case of adoption are smaller, although in the case of innovation the rent is uncertain, due to the uncertainty regarding the product of $R \& D$. The costs of adoption of existing modern technology are also fixed, but the smaller than the fixed costs of R\&D.
} 
The only research that focuses at least on some countries that are far from the technological frontiers, selected transition economics as the sample (Dutz and Vagliasindi 2000). It was demonstrated that effective competition policy had a positive effect on the growth of these countries, as more competition policy implementation led to the expansion of more efficient private firms, which was good for growth, not only because reallocation of resources from high-cost to low-cost firms, but also because of investment in the low-cost firms.

Indirect evidence that competition is good for the growth in countries that are far from the technological frontier is provided through analysis of the effects of foreign trade liberalisation, as a way of introducing competition. Tybout (2000) demonstrated that in the manufacturing sector of the developing countries the growth of output and productivity is mainly due to the liberalisation of foreign trade. Obviously, competition can be introduced this way only in the case of industries producing tradable good, but what is more important, in the case of manufacturing, increased competition produces increased output, i.e. economic growth in countries that are far from the technological frontier. ${ }^{11}$

Competition policy should not be mistaken for competition. Competition can be provided by many instruments other than competition policy, especially competition law considered separately from advocacy. Kee and Hoekman (2007) demonstrated the substantial effect of import liberalisation on competition (measured as price mark-ups), using an empirical model, cross-industry, cross-country, time series regression (sample of 28 industries, 42 counties and 18 year). It was demonstrated that the impact of competition policy is not statistically significant when control variables are imports and the number of firms in industry. Nonetheless, the number of firms is considered an outcome of competition policy-lower legal barriers to entry.

Alesina et al. (2005) provided both theoretical arguments and empirical support (in the case of OECD countries) for the thesis that deregulation based on the liberalisation of entry, i.e. removing legal barrier to entry barriers, provides an increase in investments. Although the analysis focused on heavily regulated industries (transportation, communications, and utilities), insights into the mechanism that increases the level of investments by removing the entry barriers and introducing competition are highly relevant for all industries. ${ }^{12}$

There is no controversy whether competition is good for innovation based growth, or more general, for the increase of the TFP, as an engine of growth. The more relevant the TFP increase is for economic growth, the greater the need for

\footnotetext{
${ }^{11}$ In a specific case-study, Pavcnik (2002) demonstrated that in Chile import the liberalisation of manufactured good produced a significant and sustainable increase in productivity of the manufacturing industry, partly due to the selection effect, i.e. reallocation of resources from highcost to low-cost firms. Nonetheless, the level of investments, as the consequence of liberalisation, was not analysed.

${ }^{12} \mathrm{An}$ additional important insight is that massive deregulation is needed for increasing investments to materialise-Alesina et al. (2005) found small changes in heavy regulated environment were not likely to produce the results.
} 
competition. There are several empirical studies that provide confirmation of the positive impact of competition on the TFP level and growth. Voigt (2009) empirically demonstrated (cross-section analysis, 107 countries) a statistically significant relationship between competition policy and the TFP, with more competition policy leading to an increase in the TFP. This relationship was demonstrated not only for the entire sample, but also for the subsample of countries that are far from the technological frontier, providing evidence that competition speeds up economic growth of such countries by reducing inefficiencies and improving productivity. Buccirossi et al. (2013) provided empirical evidence of a positive impact of competition policy on the increase of the TFP at the industry level ( 22 industries) in twelve OECD countries, over the course of 10 years. Furthermore, Aghion et al. (2004) empirically demonstrated in the case of the UK that more entry, due to the institutional reform that reduced legal barriers to entry, provided an increased TFP of incumbent firms and led to faster TFP growth of both incumbent and aggregate. New entries were on the technological frontiers (US FDIs), but domestic, although lagging, were not far behind - a situation described as "neck-and-neck competition". Obviously, such a constellation provided strong incentives to innovate both to the new entries and incumbent firms.

It is evident that for countries that are close to the technological frontier strong competition is favourable for economic growth, hence institutions that encourage and protect competition are desirable. Accordingly, effective competition policy is inevitable, consisting of both competition law enforcement and advocacy. The latter is important because free entry is a key prerequisite for keeping high competitive pressure on the incumbents and enabling new entries to bring their innovation to the market. Competition advocacy for import liberalisation and low barriers to entry should be an integral part of the competition policy.

Bearing all these insights in mind, the middle income convergence trap can be reconsidered within the framework of competition policy. Is the error of introducing competition policy too early greater than the error of introducing it too late? Is the damage done to investment based growth by introducing competition policy greater than the damage done to innovation based growth by not introducing it?

The answers to these questions should be based on two findings. The first one has already been considered in this paper: competition has substantial positive effects on the economic growth of countries that are far from the technological frontiers due to the incentives that it creates for improvement of efficiency and for imitation, i.e. adoption of modern technology. Furthermore, it was demonstrated that rule of law is more important for creating incentives for investments that high returns on account of market power. Contrary to that, lack of competition has no positive effect whatsoever on the economic growth of countries that are close to the technological frontier. Undoubtedly, there is a strong asymmetry regarding these relationships. Based on this asymmetry the conclusion follows: the error of introducing competition policy too early is much smaller than the error of introducing it too late.

There is an additional insight, from the political economy prospective, which supports the conclusion on asymmetrical danger. As pointed out by Aghion and Schankerman (2004), the lack of competition policy, including high legal barrier to 
entry, creates very specific winners: incumbents with substantial market power, appropriating substantial rents, who have every incentive to use theses rents to bribe legislators not to introduce competition policy, especially not to remove legal barriers to entry. Powerful incumbents, established within the framework without competition, are determined to prevent the increase of competition. This creates a specific institutional trap: lack of competition policy creates further lack of competition policy. Because of this trap, competition that is weak cannot become strong. As a consequence, if a country decides to start down the path of prosperity, without competition policy and with high legal barriers to entry, then it could end up in a low-competition trap. ${ }^{13}$

This finding is just a specific case of the political economic model created by Aghion and Schankerman (2004). Assuming that there is cost heterogeneity in the economy and that there are low-cost and high-cost firms, there are basically two institutional equilibriums: low competition and high competition. The comparative statics of the model demonstrated that countries that are most vulnerable to the low competition trap are those with a low initial level of competition, a low initial degree of cost asymmetry, and office holders more driven by their private interests than by social welfare concern. This is exactly the situation in many countries that are far from the technological frontier.

Accordingly, it is not only that the error of introducing competition policy too early is much less dangerous for convergence than the error of introducing it too late, but there is a substantial danger of the institutional trap if the country decides to move forward without competition policy and with high legal barriers to entry. Taking that into account, is there a way to detect the right timing from the ongoing macroeconomic development? More specifically, could a growth crisis be a cue for the institutional shift that will take a country away from the convergence trap? Could a government wait for the growth crisis in order to conclude that the growth model is obsolete, that the engine of growth has run out of steam, and then to initiate reforms, shifting from institutions that support investment based growth towards institutions that support innovation based growth?

For this strategy to be applied, there are two principal problems that should be kept in mind, and both are related to timing. The first is linked to the timing of the diagnosis of the growth crisis. Negative growth rates are not sufficient condition for such a diagnosis. These rates could be the consequence of output fluctuations within business cycles, i.e. a recession due to the temporary slump in demand. Or in the case in economies that do not have diversified output, negative growth rates could be the consequence of a drop in the prices of the main export commodities and deterioration of the country's terms of trade. It inevitably takes time, even for unbiased, non self-

\footnotetext{
${ }^{13}$ Similar to this trap is the high legal barriers to entry trap in oligarchic societies (Acemoglu 2008). In an oligarchy the political elite is accountable only to the business elite protected by legal barriers and earning substantial rent. Sharing of that rent provides a strong incentive for both elites not to remove those barriers. In this paper the character of political institutions is not considered as a factor or outcome of competition policy, although there are some attempts in that direction (Petersen 2013; Ma 2016).
} 
delusional governments to realise that there is a growth crises and that the growth model should be changed. The likelihood is high that it will already be too late for that.

The other timing is the one related to the institutional reform. Such a reform takes time to materialise. First it must be designed, then implementation institutions need to be developed, including training the staff, followed by a period of learning-bydoing, and finally time is needed for the deterrence to be established, before the new competition institution is fully effective.

In short, not only is the error of introducing competition policy too early much smaller, and less dangerous than the error of introducing it too late, but the probability of the error of introducing it too late is much greater. Both danger and probability are asymmetrical.

This finding clears the way for consideration of the case of SEE countries and their competition policy.

\section{SEE Countries: In the Middle of the Convergence Trap?}

Are SEE countries in the middle of a convergence trap? What is the main engine of growth of the SEE countries? Is competition good for the growth of these countries? Do they need competition policy and what kind?

A framework needs to be established in order for these questions to be answered. Part of that framework is based on the answer regarding the main features of the economies of the SEE countries, especially taking into account that, with the exception of one, all of them were once socialist countries, with administrative decision-making and compulsory mobilisation of the production factors, including the labour force. Investment rates were high and investments were allocated to manufacturing (heavy industry concept) and infrastructure. A rather high level of human capital has been achieved. Due to the legacy of the past (no market allocation of resources, no private property, no free foreign trade), most of these economies feature inefficiency and significant distance for the technological frontiers. As to the industrial structure, rather inefficient manufacturing is dominant, with some agriculture and very limited service industries. The beginning of the transition introduced market allocation of the resources, private property and created a dual economy: one segment made up of modern, greenfield, private and low-cost firms, mainly new entries, and the other made up of obsolete, incumbent, frequently state-owned, and high-cost firms - a heterogeneity with a considerable cost difference. ${ }^{14}$

The bottom line is that accumulation of the production factors was substantial, its allocation rather inefficient, and the technology used lagging behind the technological frontier, although not as much as most of the less developed countries.

\footnotetext{
${ }^{14} \mathrm{~A}$ socialist legacy of the transition economies, as well as the first transition moves, including liberalisation and privatisation, has been thoroughly analysed in Aaslund (2007).
} 
Table 1 Median distance to the technological frontier in 2014

\begin{tabular}{l|c|c}
\hline & GDP per capita & Output per worker \\
\hline SEE countries & 13 & 16 \\
\hline EU-15 & 88 & 92 \\
\hline USA & 100 & 100 \\
\hline
\end{tabular}

Source: World Bank database

Table 2 Growth accounting for CEE and SEE countries: Contribution of the production factors and TFP

\begin{tabular}{l|c|l|l|l|l|l}
\hline & \multicolumn{5}{|l|}{} & 2002-2006 \\
\cline { 2 - 7 } & Capital (\%) & Labour (\%) & TFP (\%) & Capital (\%) & Labour (\%) & TFP (\%) \\
\hline EU 10 & 2.9 & 25.6 & 77.3 & 10.6 & 21.3 & 58.1 \\
\hline WB & 13.9 & 10.4 & 75.7 & 30.6 & -17.8 & 87.3 \\
\hline
\end{tabular}

Source: Borys et al. (2008)

Notwithstanding substantial methodological issues, approximation of the distance to the technological frontier is estimated as the distance from the USA in terms of GDP per capita (Madsen et al. 2015) and output per worker (Begović et al. 2017). The median distance of the SEE countries and EU-15 are in the Table 1.

Taking all this into account, one could assume that the increase of TFP is the main engine of growth of the CEE economies. Simple growth accounting results for CEE and SEE countries (Borys et al. 2008) provided confirmation of this conjecture (Table 2). ${ }^{15}$

It is evident that the greatest source of economic growth in SEE Europe has been TFP growth, rather than production factors accumulation. ${ }^{16}$ Accordingly, competition, which is undoubtedly good for TFP growth, should be achieved through effective competition policy in these countries.

There is missing information on the structure of the of the TFP growth in the SEE countries, due to the inherent limitation of the methodology: it is not known which part of the TFP is due to technological progress and which is due to improved efficiency. From the dynamics of the TFP in the two regions, as well as from the economic features of the SEE countries and their distance from the technological frontier, it can be corroborated that most of the growth of TFP is due to the increase in efficiency, provided by the privatisation and subsequent restructuring, reallocation of resources from low-productivity to high-productivity activities (mainly from inherited manufacturing to service industries) and reallocation from high-cost to

\footnotetext{
${ }^{15}$ These results, related to the contribution of the TFP to economic growth, have been confirmed by Iridian (2007) and World Bank (2008). The considerable difference in the growth of TFP between "Old" and "New" Europe, being much higher in the latter, indirectly confirming the presented results, has been recorded by Burda and Severgnini (2009).

${ }^{16}$ This is entirely different from the case of the Southeast Asia "tigers" in the period of their intensive growth (1966-1990). The contribution of the TFP growth to the economic growth was: $30 \%$ for Hong Kong, $-5 \%$ for Singapore, $12 \%$ for South Korea, and 20\% for Taiwan. The contribution of capital accumulation was much higher: $42 \%$ for Hong Kong, $73 \%$ for Singapore, $46 \%$ for South Korea, and 40\% for Taiwan (Young 2005).
} 
low-cost firms within the same industries, with exits of high-cost firms. A smaller part of the TFP increase is due to the technological progress, mainly due to the adoption of modern technology from countries close to or at the technological frontier.

Indirect confirmation of this conjecture is a drop of the TFP growth share in the case of ten EU countries. After initial restructuring that was carried out prior to 2002, there are fewer activities that can be restructured and an increase in capital accumulation is needed for new technology to be introduced. This means that the share of TFP growth in the case of the economic growth of SEE countries will probably continue to decrease, but that is irrelevant for the finding on desirability of competition policy, since competition is good for both (local) innovation, i.e. adoption of modern technology, and for firm restructuring, and both intra- and inter-industry reallocation. Competition is a necessary precondition for TFP growth, both for the restructuring of incumbent firms and for the adoption of new technology, both by incumbents and new entries, FDIs and other investments.

Effective competition policy includes competition advocacy aimed at and improving the business environment, primarily in the direction of facilitating new entries. The business environment in the SEE countries could be analysed using three available indicators: indexes of economic freedom by The Heritage Foundation and The Wall Street Journal, and by the Fraser Institute, and ranking according to the Cost of Doing Business survey (Table 3).

It is evident that the level of economic freedom and the quality of the business environment in the median SEE country is lagging behind the median EU-15 country ("Old Europe") and, especially, behind the best score/rank. Competition law enforcement cannot do anything about that, but competition advocacy can, focusing especially to the issues of effective foreign trade liberalisation and elimination of legal barriers to entry.

Substantial trade liberalisation occurred in the process of accession to the EU. Some of the SEE countries are members of the EU (customs) union, and some have FTAs with the EU. Furthermore, there is a regional FTA arrangement in the Western Balkans, connecting non-EU member states. Accordingly, substantial barrier to trade across the border, especially tariffs and quantitative restrictions, have been eliminated. Nonetheless, there are still substantial hidden barriers to trade that should be removed and the limited capacity of the local customs administrations should be improved to increase competition through importing, and competition advocacy should focus on those barriers.

Table 3 Median indexes and ranking of the business environment in SEE countries in 2014

\begin{tabular}{l|c|l|l}
\hline & Heritage-WSJ index & Fraser institute index & Cost of doing business (rank) \\
\hline SEE countries & 62 & 74 & 47 \\
\hline EU-15 & 81 & 84 & 25 \\
\hline Best score & 100 & 100 & 1 \\
\hline
\end{tabular}

Sources: The Heritage Foundation, Fraser Institute, and The World Bank Doing Business 
In the case of barriers to new entry, competition advocacy should focus not only on the registration of new firms, which is usually swift in SEE countries, but on all effective barriers of entering the market in a specific industry. This, for example, includes the process and permissions regarding land development, provision of the infrastructure to new facilities, as well as operations of the tax administrations (compliance costs) and judicial protection of private property rights. In the globalised economy with capital being a mobile factor, all these elements create effective barriers to entry, not only strictly speaking legal barriers. The smaller the number of new entries, whatever of these reasons may be, the smaller the competitive pressure on the incumbents and the lower the prospects of adoption of new technology.

Competition advocacy should be carried out by NCAs for two obvious reasons. The first is the NCAs are knowledgeable about the mechanisms and effects of competition, and that makes them effective and efficient in competition advocacy (Ghosal 2013). The second is the economy of resources within a NCA. Not only is there a substantial economy of scope (with competition law enforcement and competition advocacy being carried out together), but there is a complementary in resource allocation: the more resources that are allocated to advocacy, with advocacy being effective, i.e. increasing competitiveness of the environment, the fewer resources will be needed for competition law enforcement. The expected effectiveness of advocacy in the SEE countries should take into account the assumption of advocacy substantial and perhaps increasing marginal returns. This assumption is based on the insight that competition culture in SEE countries is not very developed, not very widespread in the public, and that its achievements, however modest, have a rather short tradition. Competition advocacy is not the panacea for improving competition in the SEE countries, but it should definitely be a very important segment of the efforts.

\section{Elements of Competition Policy for the SEE Countries}

Most of the SEE countries have already adopted EU-style competition policy, with competition law regime very similar and in many cases identical to the EU provisions. Such a choice provided huge benefits: clear readymade solutions, a framework for training the staff that enforced the law, and, not least, a long history of case law that can be used. The problem with the EU-style competition policy adopted in the SEE countries is that it is focused to the law enforcement, not to the competition advocacy. That is quite appropriate for the old EU member states, or the core of the EU, countries with a long tradition of capitalism and market economy, but that is a disadvantage for countries where there is no long tradition of competition culture.

Accordingly, the priority for the SEE countries should be competition advocacy, focusing on two areas: foreign trade effective liberalisation and freedom to entry. As to foreign trade, substantial liberalisation has already occurred in the early transition and the process of EU accession, with removing tariff barriers and quantitative 
restrictions. Nonetheless, there are still hidden barriers to trade, especially in the Western Balkan countries, preventing foreign trade from achieving its full potential in creating substantial import competition.

As to the barriers to entry, there is a lot of room for improvement regarding various legal statutory and sub-statutory texts. Competition advocacy should address every effective legal barrier to entry, not only those barriers linked to the registration of new companies-usually they are quite limited. Substantial barriers exist in the development of the property (obtaining town-planning and development permits for new facilities), registration of the property, providing infrastructure services, and many other barriers to entry. The cost of doing business, like costs of compliance with tax regulations (efficiency of tax administration) and costs of protection of own private property rights (efficiency of the judiciary in litigations) are also effective barriers to entry, especially in the case of FDIs, which are an important vehicle for technology transfer. By removing barriers to entry, potential competition would be created, providing incentives to the incumbents to improve their efficiency, and new entries would materialise, increasing the TFP on average and speeding up the economic growth of the SEE countries.

SEE countries lag behind the EU-15 countries in both economic freedom and costs of doing business; their business environment is not beneficial for competition as it is the EU-15 countries. Institutional convergence of that kind can be achieved only through vigorous competition advocacy and public pressure created by that advocacy. This is the only way to achieve the results in institutional convergence, taking into account that private interest groups are rather well-organised in SEE countries, with high stakes in the institutional reform game. Economic freedom harms rents crated by various barriers to entry and there is strong incentive for all those appropriating these rents to prevent the institutional reforms that would increase economic freedom.

It should also be taken into consideration that the economies of the SEE countries are in the middle of the restructuring process, both in terms of intra- and interindustry reallocation of resources. Not only is competition a crucial prerequisite for this (the selection effect of competition, moving resources from high-cost to low-cost firms), but this process is carried out to a great extent through mergers and acquisitions. For that very reason it is important that merger control in SEE countries be lenient: merger control should not be a substantial barrier to restructuring in SEE economies, which would lead to a TFP increase. The best way forward would be to increase the notification thresholds. In that way, many mergers that are now obliged to be notifies and that are cleared in the first stage of the review, would not require notification at all. The costs of mergers, both in terms of resources and time, would decrease and that would speed up the restructuring process and boost the TFP increase. 


\section{Conclusion}

Competition is good for the economic growth of the SEE countries. Their growth is based on the increase in the TPF, mainly on account of the restructuring process and reallocation of resources, but also due to the adoption of modern technology. Competition provides key incentives for this type of economic growth and no disadvantage of competition has been recorded for the TFP based growth. Accordingly, effective competition policy in the SEE countries is essential for these countries to continue restructuring their economies and avoiding the middle income convergence trap. After all, from the prospective of this trap, the danger of introducing competition policy too early is much smaller than the danger of introducing it too late. In that respect, the SEE countries are on the safe side of introducing competition policy.

Taking into account that the business environment in the SEE countries still lags behind the business environment of "Old Europe", that economic freedom is somewhat curtailed, and that there are still important legal barriers to entry, advocacy should be a priority of the competition policy. Since EU-style competition policy has been widely adopted in the SEE countries and since it is not well equipped for advocacy, additional efforts are needed for designing a suitable competition advocacy strategy, allocating resources needed for effective advocacy, and changing some of the legislative provisions to grant more power to the NCAs to conduct their advocacy activities.

Competition legislation enforcement should not be neglected in the SEE countries. Nonetheless, taking into account that restructuring contributes significantly to the economic growth of these countries, and that mergers and acquisitions facilitate that process, merger control should not be an obstacle to this process. For that very reason it is important that merger control in SEE countries be lenient. The best way forward would be to increase the notification thresholds. Such a move would save some NCA resources, which can be allocated to competition advocacy.

Acknowledgment The author is grateful to Milan Kostić and Russell Pittman for their helpful comments and suggestions. The support of the Swiss National Science Foundation, program SCOPE IZ73Z0_152730, and cooperation with the Department of Economics, University of Zurich is gratefully acknowledged. Naturally, none of them is to be held accountable for possible remaining errors and value judgments in this paper.

\section{References}

Aaslund A (2007) How capitalism was built: the transformation of Central and Eastern Europe, Russia and Central Asia. Cambridge University Press, Cambridge

Acemoglu D (2008) Oligarchic versus democratic societies. J Eur Econ Assoc 6(1):1-44

Acemoglu D, Cao D (2015) Innovations by entrants and incumbents. J Econ Theory 157:255-294

Acemoglu D, Aghion P, Zillibotti F (2006) Distance to frontier, selection, and economic growth. J

Eur Econ Assoc 4(1):37-74 
Aghion P, Howitt P (2006) Joseph Schumpeter lecture - appropriate growth policy: a unifying framework. J Eur Econ Assoc 4(2-3):269-314

Aghion P, Schankerman M (2004) On the welfare effects and political economy of competitionenhancing policies. Econ J 115(498):800-824

Aghion P, Harris C, Vickers J (1997) Competition and growth with step-by-step innovation: an example. Eur Econ Rev 41(3-5):771-782

Aghion P, Harris C, Howitt P, Vickers J (2001) Competition, imitation and growth with step-bystep innovation. Rev Econ Stud 68(3):467-492

Aghion P, Blundell R, Griffith R, Howitt P, Prantl S (2004) Entry and productivity growth: evidence from microlevel panel data. J Eur Econ Assoc 2(2-3):265-276

Aghion P, Burgess R, Redding S, Zilibotti F (2005) Entry liberalization and inequality in industrial performance. J Eur Econ Assoc 3(2-3):291-302

Aghion P, Blundell R, Griffith R, Howitt P, Prantl S (2009) The effects of entry on incumbent innovation and productivity. Rev Econ Stat 91(1):20-32

Akhtaruzzman M, Berg N, Hajzler C (2017) Expropriation risk and FDI in developing countries: does returns of capital dominate returns on capital. Eur J Polit Econ 49:84-107

Alesina A, Ardagana S, Nicoletti G, Schiantarelli F (2005) Regulation and investment. J Eur Econ Assoc 3(4):791-825

Begović B (2013) The political economy context of economic growth in South East Europe. In: Anastasakis $\mathrm{O}$ et al (eds) Defining a new reform agenda: paths to sustainable convergence in South East Europe. St Antony's College, Oxford, pp 7-24

Begović B, Mladenović Z, Popović D (2017) Democracy, distance for the technological frontiers and economic growth: some empirical results, CLDS Working Paper \#0217, April 2017, Center for Liberal-Democratic Studies, Belgrade

Borys MM, Polgar EK, Zlate A (2008) Real convergence and the determinant of growth in EU candidate and potential candidate countries: a panel data approach, ECB Occasional Paper Series, No. 86, European Central Bank, Frankfurt

Buccirossi P, Ciari L, Duso T, Spagnolo G, Vitale C (2013) Competition policy and productivity growth: An empirical assessment. Rev Econ Stat 95(4):1324-1336

Burda MC, Severgnini B (2009) TFP growth in Old and New Europe. Comp Stud 51(4):447-466

Dutz MA, Hayri A (2000) Does more intense competition lead to higher growth? Policy Research Working Paper 2320, World Bank

Dutz MA, Vagliasindi M (2000) Competition policy implementation in transition economies: an empirical assessment. Eur Econ Rev 44(4-6):762-772

Easterly W, Levine R (2001) It's not factor accumulation: stylized facts and growth models. World Bank Econ Rev 15(2):177-219

Ghosal V (2013) Resource constrains and competition law enforcement. Theoretical considerations and observations from selected cross-country data. In: Sokol DD, Cheng TK, Lianos I (eds) Competition law and development. Stanford University Press, Stanford, pp 90-114

Hall RE, Jones CI (1999) Why do some countries produce so much more output per worker than others? Q J Econ 109(1):83-109

Han X, Wei SJ (2017) Re-examining the middle-income trap hypothesis: what to reject and what to revive? J Int Money Financ 73(A):46-61

Im FG, Rosenblatt D (2013) Middle-income traps: a conceptual and empirical survey, World Bank Policy Research Working Paper WPS6594, World Bank

Iridian G (2007) Rapid growth in transition economies: growth-accounting approach, IMF Working Papers, No. 07/164

Kee HL, Hoekman B (2007) Import, entry and competition law as market disciplines. Eur Econ Rev 51(4):831-858

Laffonte JJ (1998) Competition, information, and development. In: Pleskovic B, Stiglitz J (eds) Annual World Bank conference on development economics. The World Bank, Washington, DC, pp 237-257

Lu Y, Tao Z, Zhu L (2017) Identifying FDI spillovers. J Int Econ 107:75-90 
Ma TC (2016) Antitrust and democracy: perspectives from efficiency and equity. J Compet Law Econ 12(2):233-261

Maddison A (2007) Contours of the world economy, 1-2030 AD: essays in macro-economic history. Oxford University Press, Oxford

Madsen J, Raschky P et al (2015) Does democracy drive income in the World, 1500-2000? Eur Econ Rev 78(1):175-195

Pavcnik N (2002) Trade liberalization, exit, and productivity improvements: evidence from Chilean plants. Rev Econ Stud 69(1):4245-4276

Petersen N (2013) Antitrust law and the promotion of democracy and economic growth. J Compet Law Econ 9(3):593-636

Phelps ES (1966) Golden rules of economic growth. W.W. Norton, New York

Rosenstein-Rodan PN (1943) Problems of industrialisation of Eastern and South-Eastern Europe. Econ J 53:202-211

Sabirianova K, Svejnar J, Terrell K (2005) Distance to the efficiency frontier and foreign direct investment spillovers. J Eur Econ Assoc 3(2-3):576-586

Singh A (2002) Competition and competition policy in emerging markets: international and developmental dimension. G-24 Discussion Paper Series, UNCTAD, Geneva

Solow RM (1956) A contribution to the theory of economic growth. Q J Econ 70(1):65-94

Tybout JR (2000) Manufacturing firms in developing countries: how well do they do, and why? J Econ Lit 39(1):11-44

Voigt S (2009) The effects of competition policy on development: cross-country evidence using four new indicators. J Dev Stud 45(8):1225-1248

World Bank (2008) Unleashing prosperity: productivity growth in Eastern Europe and the former Soviet Union. The World Bank, Washington, DC

Young A (2005) The tyranny of numbers: confronting the statistical realities of the East Asian growth experience. Q J Econ 110:641-680

Open Access This chapter is licensed under the terms of the Creative Commons Attribution 4.0 International License (http://creativecommons.org/licenses/by/4.0/), which permits use, sharing, adaptation, distribution and reproduction in any medium or format, as long as you give appropriate credit to the original author(s) and the source, provide a link to the Creative Commons license and indicate if changes were made.

The images or other third party material in this chapter are included in the chapter's Creative Commons license, unless indicated otherwise in a credit line to the material. If material is not included in the chapter's Creative Commons license and your intended use is not permitted by statutory regulation or exceeds the permitted use, you will need to obtain permission directly from the copyright holder.

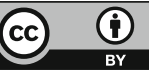

